\title{
Editorial
}

\section{INTRODUCING THE SSLA METHODS FORUM}

\section{Susan Gass*}

Michigan State University

\section{Luke Plonsky}

\section{Northern Arizona University}

SLA has always been and remains a dynamic discipline that employs an increasingly wide range of methodological techniques. Over the years there has been a steady interest in research methodology/design (cf. Dörnyei, 2007; Hatch \& Farhady, 1982; Hatch \& Lazaraton, 1991; Mackey \& Gass, 2012, 2016; Mackey \& Marsden, 2016; McKinley \& Rose, 2020; Phakiti et al., 2018). Not only have there been numerous textbooks dealing with design and methodology, entire series have been devoted to the topic of research methods (Second Language Acquisition Research, begun in 1997 and currently published by Routledge, and Guides to Research Methods in Language and Linguistics, begun in 2011 and published by Wiley-Blackwell (https://www.wiley.com/en-us/Guides+to +Research+Methods+in+Language+and+Linguistics-c-2899). More recently, however, large numbers of scholars in the field began to take on research methodology as an explicit and even empirical focus of their work (see overview by Gass et al., 2020).

Signs of this "methodological turn" (Byrnes, 2013, p. 825) can be seen in the number and variety of texts devoted to specific methods (e.g., Bowles, 2010; Conklin et al., 2018; Dörnyei \& Taguchi, 2009; Gass \& Mackey, 2017; Godfroid, 2020; Jegerski \& VanPatten, 2014; Jiang, 2012; McDonough \& Trofimovich, 2009; Spinner \& Gass, 2019), texts devoted to data elicitation (Gass \& Mackey, 2007; Rose et al., 2020), and texts devoted to statistics (Larson-Hall, 2016; Plonsky, 2015). We have also seen in recent years an increase in the frequency and popularity of methods workshops, initiatives promoting open science and replication (e.g., Marsden \& Plonsky, 2018; Porte \& McManus, 2019), methodological syntheses (e.g., Lindstromberg, 2016; Marsden et al., 2018; Plonsky \& Gass, 2011), and studies exploring statistical literacy among L2 researchers (e.g., Loewen et al., 2014, 2020). Analytically speaking, a number of new statistical techniques have been introduced such as mixed-effects modeling and Bayesian data analysis (e.g., Norouzian et al., 2018) as well as systematic reexaminations of familiar statistical

\footnotetext{
* Correspondence concerning this article should be directed to Susan Gass, 7492 Dublin Road, Delaware, OH 43015. E-mail:gass@msu.edu.
} 
techniques such as null hypothesis significance testing (e.g., Norris, 2015) and multiple regression (Plonsky \& Oswald, 2017). We view the scrutiny of and attention to methods embodied by these works as signs of the field's health and maturity.

SSLA and other journals have both welcomed and played an important part of this movement (cf. Crossley et al., 2020). This journal, for example, has enacted updated and increasingly more rigorous publication guidelines and has sought to uphold those guidelines through its peer and editorial review process. We have also published articles that not only shed light on L2 development but also those that seek to advance methodological understanding, training, and practices in the field (e.g., Hamrick \& Sachs, 2018; Keating \& Jegerski, 2015; Norouzian, 2020; Plonsky, 2013).

SSLA is now taking another step to further the field's methodological literacy by inviting authors to submit manuscripts to the Methods Forum. Articles of this type can take a number of different forms as long as the focus is on research methods as applied to SLA. Manuscripts submitted to the Methods Forum can be conceptual, presenting an argument in favor of or against a particular technique or practice. Submissions might also present empirical data whether (a) collected specifically for the methods piece, (b) simulated, or (c) based on a reanalysis of one or more existing datasets. Articles in the Methods Forum can also introduce and make a case for a novel technique or a novel combination of techniques. However, all articles in the Methods Forum will provide implications for research design, instrumentation, analysis, reporting/dissemination, interpretation, and/or methodological training in L2 research. Papers discussing methodological issues from all research paradigms, epistemologies, ontologies, and theoretical frameworks relevant to the field are welcome.

On a practical note, we encourage authors to submit to the Methods Forum with a length of up to 11,000 words.

We hope that this new venue will contribute to the ongoing methodological progress of the field and thereby also increase our individual and collective capacity to advance our understanding of L2 development. We look forward to your submissions.

\section{REFERENCES}

Bowles, M. (2010). The think-aloud controversy in second language research. Routledge.

Byrnes, H. (2013). Notes from the editor. Modern Language Journal, 97, 825-827. https://doi.org/10.1111/ j.1540-4781.2013.12051.x.

Conklin, K., Pellicer-Sanchez, A., \& Carrol, G. (2018). Eye-tracking: A guide for applied linguistics research. Cambridge University Press.

Crossley, S., Marsden, E., Ellis, N., Kormos, J., Morgan-Short, K., \& Thierry, G. (2020). Introduction of Methods Showcase Articles in Language Learning. Language Learning, 70, 5-10. https://doi.org/10.1111/ lang.12389.

Dörnyei, Z. (2007). Research methods in applied linguistics. Oxford University Press.

Dörnyei, Z., \& Taguchi, T. (2009). Questionnaires in second language research: Construction, administration, and processing (2nd ed.). Routledge.

Gass, S., Loewen, S., \& Plonsky, L. (2020). Coming of age: The past, present, and future of quantitative SLA research. Language Teaching. https://doi.org/10.1017/S0261444819000430

Gass, S., \& Mackey, A. (2007). Data elicitation for second and foreign language research. Lawrence Erlbaum Associates.

Gass, S., \& Mackey, A. (2017). Stimulated recall methodology in applied linguistics and L2 research. Routledge. 
Godfroid, A. (2020). Eye tracking in second language acquisition and bilingualism: A research synthesis and methodological guide. Routledge.

Hamrick, P., \& Sachs, R. (2018). Establishing evidence of learning in experiments employing artificial linguistic systems. Studies in Second Language Acquisition, 40, 153-169. https://doi.org/10.1017/S0272263116000474.

Hatch, E., \& Farhady, F. (1982). Research design and statistics for applied linguistics. Newbury House.

Hatch, E., \& Lazaraton, A. (1991). The research manual: Design and statistics for applied linguists. Heinle \& Heinle.

Jegerski, J., \& VanPatten, B. (Eds.). (2014). Research methods in second language psycholinguistics. Routledge.

Jiang, N. (2012). Conducting reaction time research in second language studies. Routledge.

Keating, G. D., \& Jegerski, J. (2015). Experimental designs in sentence processing research: A methodological review and user's guide. Studies in Second Language Acquisition, 37, 1-32. https://doi.org/10.1017/ S0272263114000187.

Larson-Hall, J. (2016). A guide to doing statistics in second language research using SPSS and R. Routledge.

Lindstromberg, S. (2016). Inferential statistics in language teaching research: A review and ways forward. Language Teaching Research, 20, 741-768. https://doi.org/10.1177/1362168816649979.

Loewen, S., Gönülal, T., Isbell, D. R., Ballard, L., Crowther, D., Lim, J., Maloney, J., \& Tigchelaar, M. (2020). How knowledgeable are applied linguistics and SLA researchers about basic statistics? Data from North America and Europe. Studies in Second Language Acquisition. https://doi.org/10.1017/ S0272263119000548.

Loewen, S., Lavolette, E., Spino, S., Papi, M., Schmidtke, J., Sterling, S., \& Wolff, D. (2014). Statistical literacy among applied linguists and second language acquisition researchers. TESOL Quarterly, 48, 360-388. https://doi.org/10.1002/tesq.128.

Mackey, A., \& Gass, S. (2012). Research methods in second language acquisition: A practical guide. WileyBlackwell.

Mackey, A., \& Gass, S. (2016). Second language research: Methodology and design (2nd ed.). Routledge.

Mackey, A., \& Marsden, E. (2016). Advancing methodology and practice: The IRIS repository of instruments for research into second languages. Routledge.

Marsden, E., \& Plonsky, L. (2018). Data, open science, and methodological reform in second language acquisition research. In A. Gudmestad \& A. Edmonds (Eds.), Critical reflections on data in second language acquisition (pp. 219-228). John Benjamin.

McDonough, K., \& Trofimovich, P. (2009). Using priming methods in second language research. Routledge.

McKinley, J., \& Rose, H. (Eds.). (2020). The Routledge handbook of research methods in applied linguistics. Routledge.

Norouzian, R. (2020). Sample size planning in quantitative L2 research: A pragmatic approach. Studies in Second Language Acquisition. Advance online publication. https://doi.org/10.1017/S0272263120000017

Norouzian, R., De Miranda, M., \& Plonsky, L. (2018). The Bayesian revolution in second language research: An applied approach. Language Learning, 68, 1032-1075. https://doi.org/10.1111/lang.12310.

Norris, J. M. (2015). Statistical significance testing in second language research: Basic problems and suggestions for reform. Language Learning, 65 (Supp. 1), 97-126. https://doi.org/10.1111/lang.12114

Phakiti, A., De Costa, P., Plonsky L., \& Starfield, S. (Eds.) (2018). The Palgrave handbook of applied linguistic research methodology. Palgrave.

Plonsky, L. (2013). Study quality in SLA: An assessment of designs, analyses, and reporting practices in quantitative L2 research. Studies in Second Language Acquisition, 35, 655-687. https://doi.org/10.1017/ S0272263113000399.

Plonsky, L. (2015). Advancing quantitative methods in second language research. Routledge.

Plonsky, L., \& Gass, S. (2011). Quantitative research methods, study quality, and outcomes: The case of interaction research. Language Learning, 61, 325-366. https://doi.org/10.1111/j.1467-9922.2011.00640.x.

Plonsky, L., \& Oswald, F. L. (2017). Multiple regression as a flexible alternative to ANOVA in L2 research. Studies in Second Language Acquisition, 39, 579-592. https://doi.org/10.1017/S0272263116000231.

Porte, G., \& McManus, K. (2019). Doing replication research in applied linguistics. Routledge.

Rose, H., McKinley, J., \& Baffoe-Djan, J. B. (2020). Data collection research methods in applied linguistics. Bloomsbury Academic.

Spinner, P., \& Gass, S. (2019). Using judgments in second language acquisition research. Routledge. 